\title{
Significance of Retention Strategies in Business Services Sector
}

\author{
Hannah Fredrick, Joy Christy Hemema
}

\begin{abstract}
One of the chief concerns of Business Service Sector is retaining efficient employees. The recruiting team in an organization spends time on identifying candidates and training them, to equip them to be made suitable for the job. If the recruited staff quits without repaying for what he has gained, it results in a setback for the organization. Higher rates of employee's turnover, which occurs due to increasing competition in labor market, forces the organization to start its work right from the scratch of hiring, training and fostering new entrants. In addition to the financial loss the organization faces due to employee turnover, there is fading employee morale, transfer of knowledge to competitors, and negative impact on the reputation of the organization. The organizations' have therefore to adopt suitable retention strategies to retain efficient employees. Responses were elicited from employers working in various organizations in Business service sector to explore the need to adopt retention strategies, identify the retention strategies implemented by them, and to discover the importance given to retention strategies. Suitable statistical techniques such as SPSS 20.0 and AMOS have been implemented to derive at reliable conclusion.
\end{abstract}

Keywords : Employee turnover, Retention, Strategies, Organization, Financial loss, Employees morale.

\section{INTRODUCTION}

Retention is one of the burning problems in Business Service sector. it is crucial for the recruiters to recruit the right employee in the right job. Employers are in race forth best talented employees. According to Carsen (2002)“Cost of employing new employees vary as it includes advertisement cost and salary for recruiters". Thought the employers hope new talented employee will stick on to their job for at least impacts on the organization.

Retention strategies are therefore needed to be implemented in the organization for their survival. It is not easy task for the human resource management to replace the quitting employees. Retention strategies will boost the employee's happiness at workplace and also create fidelity towards the organization.

Revised Manuscript Received on December 05, 2019.

* Correspondence Author

Dr. Hannah Fredrick*, Associate Professor \& Research Supervisor, Department Of Commerce, Madras Christian College (Autonomous), Affiliated To University Of Madras, East Tambaram ,Chennai. Mail Id: hfgfef@gmail.com

Joy Christy Hemema, Research Scholar, Department Of Commerce, Madras Christian College (Autonomous), Affiliated To University Of Madras, East Tambaram,Chennai. Mail Id: joytimon@gmail.com than 5 to 7 years, in reality it is it is not so this adversely

\section{A. Need for the study}

Retaining capable and talented employees is the key to success for any organization. As doors are to attract these employees and losing them cost heavily on the organization. The study therefore focus on the cause for retaining employees and the strategies the organization can adopt to retain their employees.

\section{B. Research Gap}

Only very few studies have been made on the causes for implementing retention strategies and strategies to be implemented to retain employees..

\section{REVIEW OF LITERATURE}

Lucas (2013) accounted that “employers don't understand the expense of high employee turnover as recruiting new staff is costly".Baker (2006) is of the view that hiring new employees is difficult and costlier than to retain the current employees. It's therefore essential for every management to spotlight on implementing strategies to retain employees. Pritchard (2007)research reveals "one of the retention programs is training the employee". Kroon \& Freese (2013) in his study has pointed out that "Knowledge and skills that exiting employees takes out of the organization results in a huge loss."

\section{RESEARCH METHODOLOGY}

\section{A. Sampling design}

The sample was taken from employees working in Business Servicessector in Chennai, Tamil Nadu. Chennai was selected as it is populated city with various Business Services. As the problem of retention is predominant in Business Services, employees from this sector was chosen as sample. Questionnaire on causes for retaining employees and retention strategies to be implemented was pre-tested among few respondents to confirm questions. The questionnaire was administered to 250 respondents working in Business Services units. After discarding questionnaires that was incomplete, 225 questionnaires were selected for the study.

\section{B. Objectives}

1. Identifying the causes for retaining employees in the Business Services sector.

2. To explore retention strategies implemented by IT Sector and Other Business Services Sector.

\section{DATA ANALYSIS}




\section{Significance of Retention Strategies in Business Services Sector}

A. Application of Structured Equation Model (SEM) to identify Cause for retaining employees in Business Service Sector.

Factor Analysis -Cause for retaining employees in Business Services Sector

In order to explore the Causes for retaining employees in Business Service Sector, 18 variables were identified. Factor analysis using SPSS 21 is applied on these variables with Principal Component method and Varimax rotation. Kaiser-Meyer-Olkin Statistic was found to be 0.865 (>0.7) and Barlett's test of Spericity $(\square 2=2858.898, \mathrm{p}=0.000$ ) was found significant with a cumulative $\%$ as 69.031 , which thereby confirms the feasibility of factor analysis. One variable ' Low work group synergy' was found to have small coefficients with absolute values below 0.5 was ignored. Finally, 3 factors were identified Cause for retaining employees was named as Performance, Work Climate and Finance. The variables that constitute the 3 factors are shown below.

Table - 1: Rotated Component Matrix ${ }^{a}$ cause for implementing Retention Strategies

\begin{tabular}{|l|c|c|c|c|}
\hline \multirow{2}{*}{} & \multicolumn{2}{|c|}{ Component } \\
\cline { 2 - 4 } & $\mathbf{1}$ & $\mathbf{2}$ & $\mathbf{3}$ & \\
\hline Training expenses & .883 & & & \\
Interview cost & .874 & & & \\
Loss due to employee turnover & .872 & & & \multirow{2}{*}{ Finance } \\
Financial demands from existing employees & .789 & & & \\
Equipment cost on new entrant & .779 & & & \\
Supervising new entrants & .645 & & & \\
Stipend paid to new entrants & .639 & & & \\
\hline Transfer of knowledge & & \multirow{2}{*}{ Performance } \\
Delay in achieving organizational goals & & .866 & & \\
Performance differential among employees & & .848 & & \\
Negative employee attitude & & .817 & & \\
Disruption in operations & & .814 & & \\
Low work group synergy & & & .911 & \\
\hline Employee belongings & & & .887 & \\
Team sprit & & & .879 & Work climate \\
Employee sense of achievement & & & .741 & \\
Employee morale & & & \\
Relationship with colleagues & & & \\
\hline
\end{tabular}

\section{Inference}

Factor analysis reveals 3 factors - Finance, Performance, Work climate as the Cause for retaining employees.

\section{Confirmatory Factor Analysis (CFA)}

After the completion of Exploratory Factor Analysis, the variables in each factor obtained through Factor Analysis was confirmed by CFA using Amos 21.0. Using a maximum likelihood estimation method on each of the variables, CFA signifies if the new model fits the data well or not. The variables removed are 'Supervising new entrants' and 'Stipend paid to new entrants' from the construct 'Finance', since their contribution to the model was not appropriate.

Table - 2: Reliability and Validity for Causes for retaining employees

\begin{tabular}{|c|c|c|c|c|c|c|}
\hline & Reliability & \multicolumn{5}{|c|}{ Validity } \\
\hline & \multirow{2}{*}{ Alpha>0.7 } & \multirow{2}{*}{$\begin{array}{l}\text { AVE } \\
>0.5\end{array}$} & \multirow{2}{*}{$\begin{array}{c}\text { Composite } \\
\text { Reliability }>0.7\end{array}$} & \multicolumn{3}{|c|}{ Discriminant Validity } \\
\hline & & & & Finance & Performance & Work Climate \\
\hline Finance & .845 & .679 & .804 & .824 & & \\
\hline Performance & .890 & .673 & .911 & $.199 * *$ & .820 & \\
\hline Work Climate & .910 & .696 & .918 & $.149 *$ & $.199 * *$ & .834 \\
\hline
\end{tabular}

Source: Analysis of survey data

Alpha $>0.70$ (Nunnally\&Berstein 1994), AVE $>0.50$ (Ahmad et.al.2016),CR >0.70(Fornell and Bookstein, 1982)** Correlation significant 0.01. ** Correlation significant 0.05 .

Above table signifies that the data used in the model are found to be reliable and valid. The Fitness of Data was tested using the Model fit data in Amos and is shown in Table.3. 
Table - 3: Fit Statistics for the Measurement Model of Causes for retaining employees

\begin{tabular}{|c|c|c|c|}
\hline Name of the Index & Index Value & Acceptance level & Outcome \\
\hline RMSEA & .078 & $\leqslant 0.08$ ( MacCallum et al, 1996) & Good fit \\
\hline CFI & .957 & $\geqslant 0.95$ (Hulland et.al, 1991) & Good fit \\
\hline SRMR & .0536 & $\leqslant 0.08$ Hu \& Bentler & Good fit \\
\hline$\chi^{2 / d f}$ & 2.335 & $<5$ (Marsh et.al, 1985) & Good fit \\
\hline
\end{tabular}

Source: Analysis of survey data

The values of $\chi 2 / d f, C F I, S R M R$ and RMSEA indicated a perfect fit.

\section{Standardized regression estimates for the relationship between the Cause for retaining employees and the Factors of retention}

Having got the model fit, the Regression weights estimates are analyzed. The Regression estimates provide the relative importance between the constructs - Finance, Performance and Work Climate to the Latent variable - Causes for retaining employees. The estimates with the largest value represent the most important dimension in terms of Causes for retaining employees.

\section{Table - 4: Causes of retaining employees}

\begin{tabular}{|c|c|}
\hline Factors & Standardized Estimate \\
\hline Performance <--- Causes for Retention & .508 \\
Work Climate <--- Causes for Retention & .430 \\
Finance <--- Causes for Retention & .416 \\
\hline
\end{tabular}

Inference

Looking at the above table, it is revealed that Performance(.508) has been the major Causefor retaining employees followed by Work climate (.430) followed by Finance(.416).

Structural Equation Model showing the Causes for retaining employees

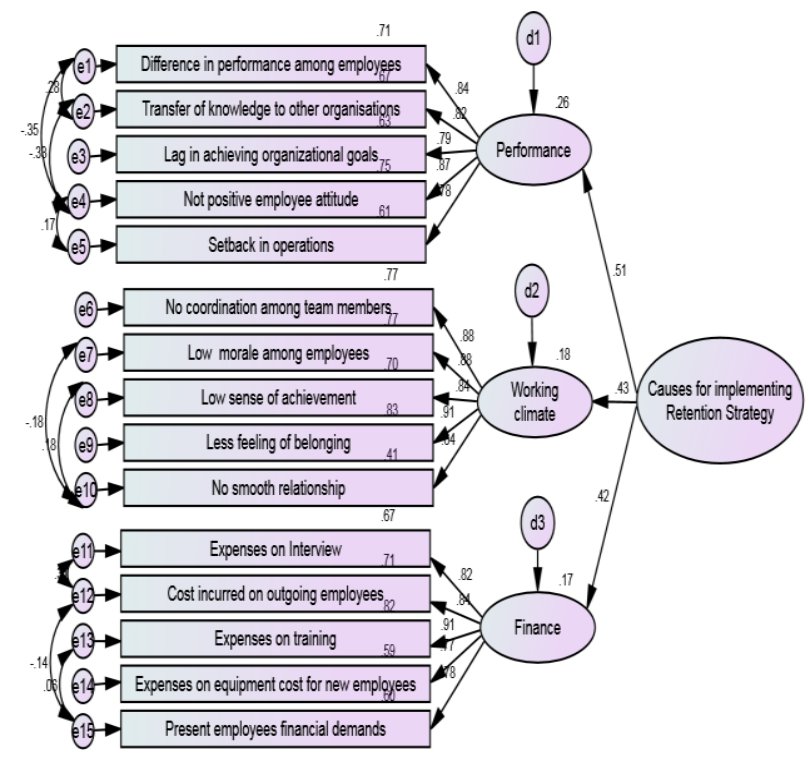

Figure - I: Structural Equation Model of the Causes for retaining employees
Table - 5: Constructs in the Causes for Retaining employees

\begin{tabular}{|c|l|c|}
\hline S.No & \multicolumn{1}{|c|}{ Factors } & $\begin{array}{c}\text { Standardized } \\
\text { Estimate }\end{array}$ \\
\hline & \multicolumn{1}{|c|}{$<--$ Performance } & \\
1. & Not Positive Employee attitude & .869 \\
2. & Difference in performance among employees & .841 \\
3. & Performance & .818 \\
4. & Transfer of knowledge to other organizations<--- Performance & .793 \\
5. & Delay in achieving organizationalgoals <--- Performance & .778 \\
6. & Disruption in operation <--- Performance & .913 \\
7. & Less belongings <--- Working Climate & .879 \\
8. & Less team spirit <--- Working Climate & .880 \\
9. & Less sense of achievement <--- Working Climate & .836 \\
10. & Less morale<--- Working Climate & .636 \\
11. & Not smooth relationship <--- Working Climate & .908 \\
12. & Training expenses <--- Finance & .845 \\
13. & Cost for outgoing employees<--- Finance & .818 \\
14. & Interview cost<--- Finance & .776 \\
15. & Financial demands from existing employees <--- Finance & .767 \\
\hline
\end{tabular}

\section{Inference}

The above model reveals that 'Negative employee attitude, performance differential among employees, transfer of knowledge, and delay in achieving organizational goal and disruption in operation are variables for the Cause for retaining employees with regards to Performance. With regards to Work climate it is less belonging, less team spirit, less sense of achievement, less employee morale and not smooth relationship. With regards to Finance it is training expenses, cost for outgoing employees, interview cost, financial demands from existing employees and equipment cost on new entrant.

Identification of Retention strategies implemented by ITBusiness Service sector and Other Business Service sector

To identify retention strategies implemented by ITBusiness Service sector and Other Business Service sector, various Retention Strategies implemented by the Business Service Sector was identified from previous research studies. The researcher adopted Descriptive statistics to analyze the results and derive at reliable conclusion. The sample consisted of 80 employees from IT-Business Service sector and 145 employees from Other Business Service sector. Table. 6 shows the Retention Strategies implemented by ITBusiness Service sector and Table 7 shows Retention Strategies implemented by Other Business Service sector.

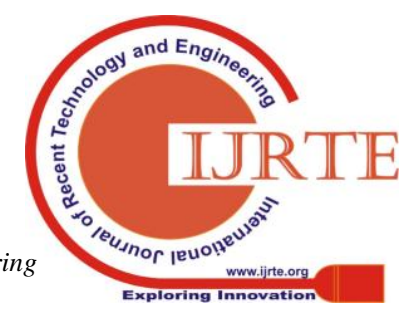


Table - 6: Descriptive Statistics of Retention Strategies implemented by IT- Business Service sector

\begin{tabular}{|c|l|c|}
\hline $\begin{array}{c}\text { Sl. } \\
\text { No }\end{array}$ & & Mean \\
\hline 1. & Freedom to excel & 4.98 \\
\hline 2. & Team flexibility & 4.83 \\
\hline 3. & Team Outing Bonding & 4.80 \\
\hline 4. & Encourage Referral Recruitment & 4.71 \\
\hline 5. & Provide Compensation Benefits at Market Rate & 4.65 \\
\hline 6. & Early Identification Problem & 4.64 \\
\hline 7. & Involve Employees Strategic Planning & 4.53 \\
\hline 8. & Providing High Quality Training & 4.49 \\
\hline 9. & Rewards based on Performance & 4.35 \\
\hline 10. & Conduct Exit Interview & 4.23 \\
\hline 11. & Hold 6 months Interview & 4.11 \\
\hline 12. & Identifying Employees Life Problems & 3.95 \\
\hline
\end{tabular}

Table - 7: Descriptive Statistics Retention Strategies implemented by Other Business Service sector

\begin{tabular}{|r|l|c|}
\hline $\begin{array}{r}\text { Sl. } \\
\text { No. }\end{array}$ & & Mean \\
\hline 1. & Freedom To Excel & 5.92 \\
\hline 2. & Team Outing Bonding & 5.87 \\
\hline 3. & Provide Compensation Benefits at Market Rate & 5.86 \\
\hline 4. & Early Identification Problem & 5.78 \\
\hline 5. & Rewards based on Performance & 5.59 \\
\hline 6. & Team Flexibility & 5.41 \\
\hline 7. & Encourage Referral Recruitment & 5.40 \\
\hline 8. & Providing High Quality Training & 5.34 \\
\hline 9. & Conduct Exit Interview & 5.28 \\
\hline 10. & Involve Employees Strategic Planning & 5.25 \\
\hline 11. & Identifying Employees Life Problems & 5.17 \\
\hline 12. & Hold 6 months Interview & 5.02 \\
\hline
\end{tabular}

\section{Inference}

As questions were asked in a rating scale ranging from 7 to 1 with 7 showing very high implementation of Retention Strategy to 1 showing very low implementation of Retention Strategy, the researcher thought it fit to consider values ranging from 3 to 1 as Low implementation of Retention Strategy, values ranging from greater than 3 to less than 5 as Moderate implementation of Retention Strategy and values ranging from 5 to 7 as High implementation of Retention Strategy.

Looking at Table.6 It is clear IT- Business Service sector has mean values ranging from 4.98 to 3.95 which implies that they show Moderate implementation of Retention Strategy. The important Retention Strategies moderately implemented by them are 'freedom to excel', 'team flexibility', 'team outing bonding', 'encourage referral recruitment', and 'provide compensation benefits at market rate'.

Looking at Table. 7 It is clear Other Business Services has mean values ranging from 5.92 to 5.02 which implies that they show High implementation of Retention Strategy. The important Retention Strategies Highly implemented by them are 'freedom to excel', 'team outing bonding', 'provide compensation benefits atmarket rate', 'early identification ofproblem', and 'rewards based on performance'.

\section{CONCLUSION}

A retention strategy is found to be of great significance in Business Service Sector with the impact on performance seen as the major Cause for implementing retention. The impact on performance is mainly shown in the form of negative employee attitude in work, performance differential among employees, and the transfer of knowledge gained in the organization to other organizations. The impact on work culture is seen as less employee belonging, less team spirit and less sense of achievement. Finance is also affected by the organization as it faces lose due to training expenses, cost for outgoing employees and interview cost. Retention strategies are seen to be seriously implemented by organization in Other Business Service sector compared to IT- Business Service sectors as they may be facing problems due to retention. They therefore implemented Retention Strategies such as freedom to excel, team outing bonding, team flexibility, provide compensation benefits at market rate, early identification of problems and rewards based on performance. Hence identifying the Cause for Retaining employees and implementing suitable Retention Strategies reveals the significance of Retention strategies in Business Service sectors.

\section{REFERENCES}

1. Ahmad,S. Bangash, H.,\&Ahmad Khan, S.(2009).Emotional Intelligence and Gender Differences. Sarhad J. Agric., Volume:25, Pp.no:1

2. Baker, E. (2006). The Human Factor. CIO Insight, 73, 40-50

3. Carsen, J.A. (2002), HR How to: Employee Retention. Chicago: Catherine Wolfe

4. Fornell, C. and Bookstein, F. L. (1982). Two structural equation models: LISREL and PLS applied to consumer exit-voice theory. Journal of Marketing Research, 19(4), 440-453.

5. Hu, L., \&Bentler, P. M. (1999). Cutoff criteria for fit indexes in covariance structure analysis: Conventional criteria versus new alternatives. Structural Equation Modeling, 6, 1-55.

6. Hulland, J, Chow, YH \& Lam, S 1996, 'Use of casual models in marketing research: A review', International Journal of Research in Marketing, 13, pp. 181-197

7. Kroon, B. and Freese, C. (2013) Can HR Practices Retain Flex workers with Their Agency? International Journal of Manpower, Volume: 34, Pp.no: 899-917. http://dx.doi.org/10.1108/IJM-07-2013-0169

8. Lucas, S. (2013). How much employee turnover really cost you? Retrieved from

Inc.

https://www.go2hr.ca/articles/employee-turnover-how-much-it-costing-yo $\mathrm{u}$

9. MacCallum, R.C., Browne, M.W., and Sugawara, H., M. (1996), "Power Analysis and Determination of Sample Size for Covariance Structure Modeling," Psychological Methods, Volume: 1, Issue: 2, Pp.no: 130-49.

10. Marsh, H. W., \&Hocevar, D.(1985), Application of confirmatory factor analysis to the study of self-concept: First- and higher-order factor models and their invariance across groups. Psychological Bulletin, 97, 562-582.

11. Nunnally, J. C., \&Berstein, I. H.,(1994), 'Psychometric theory', 3rd edn, Mc-Graw-Hill, New York.

12. Pritchard CW (2007). 101 Strategies for recruiting success: where, when, and how to find the right people every time. New York: AMACOM

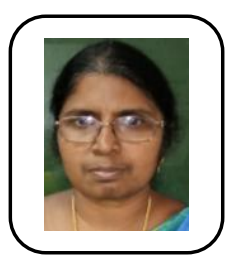

\section{AUTHORS PROFILE}

Dr. (Mrs). Hannah Frederick, M Com, M Phil, $\mathrm{Ph} . \mathrm{D}$ is working as Associate Professor in Commerce, at the Deprtment of Commerce, Madras Christian College. Her has a total teaching experirence of 28 years. Her area of specialisation is Finance and Human resource management. She has produced one research scholar and is at present guidng five research scholars towards $\mathrm{Ph} . \mathrm{D}$ 
She has also produced 7 M.Phil scholars. She has published 14 research articles in 3 National journals, 4 International journals, 6 UGC approved journals and 1 scopus Journal of which some were awarded the best paper. She is specialised in applying the latest statistical tools in research. She has chaired a session at a conference held by XIME, Bangalore. She has also delivered a lecture on Research Methodology at WCC. At present she is the member of the College Senatus and has held different positions at the college.

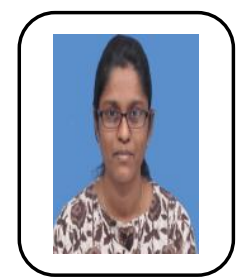

Mrs. Joy Christy Hemema, M com (cs), MBA, M phil ia full time Research Scholar (Commerce) at Madras Christian College, Chennai. Affiliated to University of

Madras. She has published 3 research articles in various national and international journals. Actively participating and presenting various research articles in various international and national conferences across the country. 